\title{
Noć knjige; Škola narodnog zdravlja „Andrija Štampar“ 24. travnja 2017 World Book Night; School of Public Health “Andrija Štampar" April 24 ${ }^{\text {th }}, 2017$
}

\author{
Sanda Franković , Zvonimir Kralj² \\ 1 Škola za medicinske sestre Mlinarska, Mlinarska cesta 24, \\ ${ }^{2}$ Zdravstveno veleučilište Zagreb, studij sestrinstva, Mlinarska cesta 38, student
}

Received May $2^{\text {nd }}$ 2017;

Accepted May $2^{\text {nd }} 2017$;

\author{
Ključne riječi: Noć knjige • Društvo za povijest sestrinstva • povijest \\ Keywords: World Book Night • History • Society for nursing history \\ Kratki naslov: Noć knjige 24. travnja 2017. \\ Running head: World Book Night April 24th, 2017
}

Autor za korespondenciju/Corresponding author: Sanda Franković, bacc. med. techn., prof., Medicinska škola Mlinarska, Mlinarska cesta 34, 10000 Zagreb•E-mail: sfrankovic@gmail.com

Noć knjige manifestacija je koja u središte interesa stavlja knjigu, autora, čitanje i čitatelja, nastojeći barem na trenutak skrenuti pozornost na ljepotu i značenje pisane riječi. Noć knjige 2017. obilježana je u 234 grada i mjesta širom Republike Hrvatske [RH]. Više od 500 sudionika: knjižnice, knjižare, nakladnici, odgojno-obrazovne ustanove, instituti, kulturni centri, bolnice, muzeji, udruge pisaca i ljubitelja knjige pripremilo je za taj dan 1057 različita programa. I ove godine u događanjima je sudjelovalo Društvo za povijest sestrinstva Hrvstske udruge medicinskih sestara [HUMS-a] u knjižnici Škole narodnog zdravlja "Andrija Štampar“ [ŠNZ] [1].

Od 2013. godine Društvo za povijest sestrinstva sudjeluje u Noći knjige u knjižnici Škole narodnog zdravlja „Andrija Štampar“. Tako je 2013. godine prikazana revija povijesnih sestrinskih uniformi i održano predavanje o povijesti sestrinstva u RH $[2,3]$.

Tema 2014. godine bili su domaćinsko-higijenski tečajevi. Škola narodnog zdravlja je u razdoblju od 1927. do 1937. godine organizirala ukupno 262 domaćinsko-higijenska tečaja za polaznice u Turopolju, Podravini, Hrvatskom zagorju, srezovima Jastrebarsko, Karlovac i Vrbosko, te u Lici i Hrvatskom primorju. Program tečajeva nije obuhvaćao samo kuhanje, nego i edukaciju o prehrani, higijeni prehrane, konzerviranju hrane, domaćinstvu, anatomiji i fiziologiji, zaraznim bolestima, njezi djece i bolesnika, općoj higijeni i higijeni žene te prvoj pomoći. Sestra Ani Papailiopulos vodila je mnoge domaćinske tečajeve, a 1934. godine napisala je knjigu naslova „O kuhanju“. Društvo za povijest sestrinstva pripremilo je kratak igrokaz o sestri Ani Papailiopulos i tečajevima koje je vodila. Kostimirane učenice Škole za medicinske sestre Mlinarska odigrale su scenski prikaz tečajeva koji su se održavali na selima u organizaciji Škole narodnog zdravlja. Vizualnom prezentacijom higijensko-domaćinskih tečajeva sestre Ani Papailiopulos posjetitelji su mogli osjetiti dašak prošlih vremena, a kako su im podijeljeni originalni recepti iz njezine kuharice, tko je želio mogao je isprobati prokušane recepte naših baka i prabaka [4,5]. Središnji dio programa Noći knjige 2015. godine bio je posvećen predavanju i izložbi sestrinskih broševa. Ovom izložbom na jednome su mjestu okupljeni broševi koje su dobivale njegovateljice i medicinske sestre u razdoblju od 1922. godine do danas na području RH. Predstavljen je sestrinski kalendar za 2015. godinu s motivima sestrinskih broševa i promovirana je knjiga autorice Snježane Grković Janović „Sestrinska riječ: između sućuti i dužnosti“. Knjiga je većim dijelom nastala crpljenjem materijala iz fonda knjižnice ŠNZ-a. Knjiga je posvećena strukovnom listu Sestrinska riječ koji je izlazio od siječnja 1933. do svibnja 1940. godine, a tiskan je upravo u tiskari Škole narodnog zdravlja. List je bio glasilo diplomiranih sestara pomoćnica, a glavna urednica bila je Lujza Janović Wagner, jedna od najzaslužnijih sestara u povijesti hrvatskog sestrinstva. Knjiga je posveta jednoj cijeloj profesiji koja se hrabro suprotstavila bolesti, siromaštvu i neznanju u razdoblju između dvaju svjetskih ratova [6,7].

Noć knjige u ŠNZ-u 2016. godine započela je predstavljanjem knjige Željka Dugca: “O sestrama, siromašnima i bolesnima: slike socijalne i zdravstvene povijesti međuratnog Zagreba", koju je izdala nakladnička kuća Srednja Europa 2015. godine, a predstavili su je urednik knjige prof. dr. sc. Damir Agičić, recenzent doc. dr. sc. Ivica Šute s Odsjeka za povijest Filozofskog fakulteta u Zagrebu, predsjednica Društva za povijest sestrinstva HUMS-a prof. Sanda Franković i autor prof. Dugac. [slika 1]

Prof. Dugac istaknuo je da ga je na pisanje knjige i istraživanje djelovanja sestara u međuratnom Zagrebu motivirala slaba obrađenost te teme u historiografiji, odnosno nepoznavanje važnosti socijalnog i medicinskog rada medicin- 


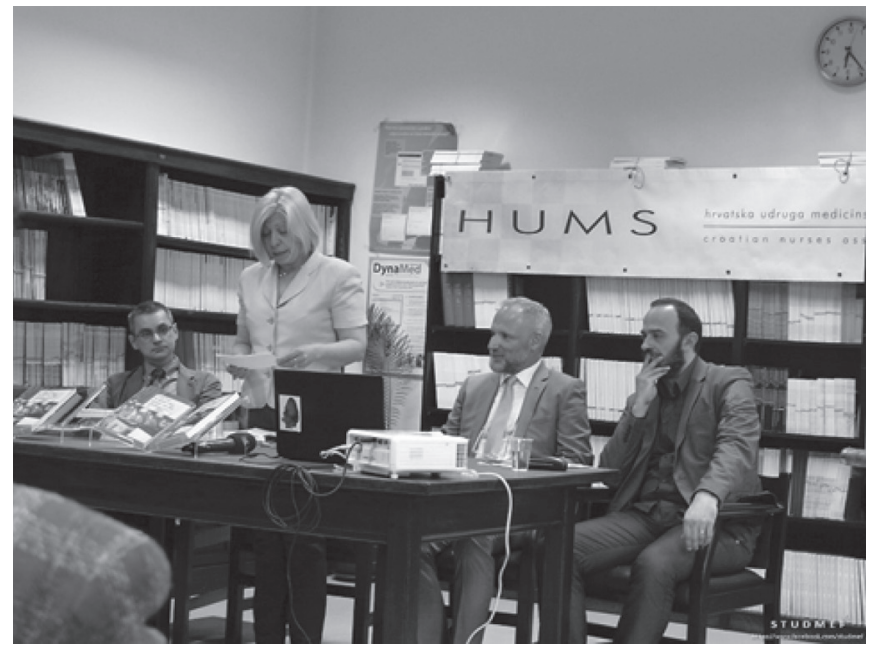

SLIKA [1] Predstavljanje knjige "O sestrama, siromašnima i bolesnima: slike socijalne i zdravstvene povijesti međuratnog Zagreba"; prof. dr. sc. Damir Agičić, prof. Sanda Franković, prof. dr.sc. Željko Dugac i doc. dr. sc. Ivica Šute.

skih sestara, tj. sestara pomoćnica između dva rata na ovim prostorima. U knjizi su opisani početci socijalne politike $u$ međuratnoj Hrvatskoj i Jugoslaviji te društvene prilike u kojima se ona oblikovala. Autor upozorava na složenost djelovanja sestara pomoćnica kao ključ razumijevanja socijalnomedicinskih koncepcija, ali i općenito javnozdravstvenog sustava međuratnog doba. Budući da se rad sestara prilagođavao potrebama društva, znatan dio knjige posvećen je analizi strukture korisnika njihove pomoći. Tako istraživanje rada pripadnica jedne profesije postaje složen prikaz života jednoga društvenoga sloja i načina kako je država nastojala uspostaviti institucionalnu brigu za najugroženije. Knjiga je prikaz znanstvenih i socijalnih ideja međuratnog vremena te nastojanja da se profesionalizira jedan oblik tradicionalno ženskog zanimanja. Nakon predstavljanja knjige uslijedilo je predavanje "Hrvatska udruga medicinskih sestara - povijest koja obvezuje" koje je održala prof. Sanda Franković. U izlaganju je prikazana povijest nacionalne sestrinske udruge. Izneseni su izvori koji upućuju na početke udruživanja sestara na našim prostorima prije 1929. godine, koja se službeno smatra godinom osnutka udruženja kojeg je nasljednik HUMS. Prikazane su aktivnosti i izdavačka djelatnost udruge koje svjedoče o iznimnoj važnosti HUMSa u profesionalizaciji sestrinstva u RH. U velikoj čitaonici knjižnice "Andrija Štampar" Društvo za povijest sestrinstva organiziralo je i izložbu plakata stručnih društava HUMS-a. Plakatima je prikazan dosadašnji rad i približen povijesni razvoj društava HUMS-a koji čine okosnicu stručnih aktivnosti Udruge. Predstavljen je Sestrinski kalendar za 2016. godinu s motivima sestrinskih broševa. Uz slikovne prikaze broševa kalendar je obogaćen datumima i opisima istaknutih događaja iz povijesti hrvatskog sestrinstva, tako da je njegova uloga promotivna i edukativna [8].

Program u Medicinskoj školi Bjelovar započeo je uvodnom riječi Marine Šostarić, a zatim je uslijedilo predavanje Sestrinski broševi kroz povijest koje je održao Zvonimir Kralj. Ogranizirana je izložba sestrinskih broševa i predstavljen Sestrinski kalendara za 2016. godinu [9].
Noć knjige 2017. godine je otvorena predavanjem Darije Hofgräff i Sande Franković „Osnutak prve medicinske škole u Hrvatskoj: učenice mlade, neporočne, i zdrave". U predavanju su prezentirani historiografski podaci sakupljeni u arhivskim fondovima Hrvatskog državnog arihva i Državnog arhiva u Zagrebu, službenim publikacijama Narodnih novina i službenih listova i do sada objavljene literature vezane uz povijest škole. Prikazani su podaci vezani uz datum osnivanja škole, početak i trajanje nastave za prvu generaciju učenica te broj upisanih i ispisanih učenica, kao i završenih sestara u prvoj generaciji. Predavanje naziva „Povijest Pulmološkog društva Hrvatske udruge medicinskih sestara" održala je Tatjana Munko. Predstavljena je povijest Pulomološkog društva koje je svojim radom započelo 25. studenog 1974. godine. U predavanju je izložen rad jednog od najstarijih društava HUMS-a i najavljeno izdavanje monografije. U prostorijama knjižnice izloženi su Bilteni Pulmološkog društva izdavani od 1975. do 1989. godine, a izložbu su pripremile Jasminka Ban Grahovac, Slađana Režić i Božica Jurinec.

Noć knjige završena je predstavljanjem knjige "I opet bih bila sestra - svjedok jednog vremena", autorice Stane Lovrić. Knjigu su predstavile urednice knjige Rosana Svetić Čišić, Sanda Franković i sama autorica. [slika 2]

Jedna od urednica knjige, Sanda Franković, naglasila je: “... da knjiga nije samo bogata biografija medicinske sestre koja je u svjetu sestrinstva djelovala pedeset godina, već da je knjiga iznimno slojevita i može se čitati na mnogo načina. Ona govori o selu i životu obitelji nakon II. svj. rata. Težini raspadanja seoskih obitelji i pustošenju seoskog prostora u kojem je čuvana mudrost teško razumljiva "asfaltiranom" čovjeku. Govori o nemirima koji opsjedaju dušu mladoga čovjeka i pozvanosti i ponosu da se služi potrebitima. Priča je to o entuzijazmu da se bolničko okruženje učini prostorom u kojem je čovjek vidljiv i nastojanjima da se volonterskim radom unaprijedi skrb. Spominje se sudbina ljudi u Domovinskom ratu, njihova hrabrost i opredjeljenosti da djeluju časno u uvjetima koji donose mnoge etičke dileme i kušnje. Donosi beznađe ratom poharanih mjesta gdje i u takvim prilikama nalazimo iskre veselja. Govori o entuzijazmu s kojim je stvaran hospicijski pokret. U knjizi nalazimo povijest razvoja profesionalne udruge kao temelja na kojem počiva današnji rad sestara u našoj zemlji. Ali govori i o veselju, predanosti i stvaranju toplog suradničkog i prijatelj-

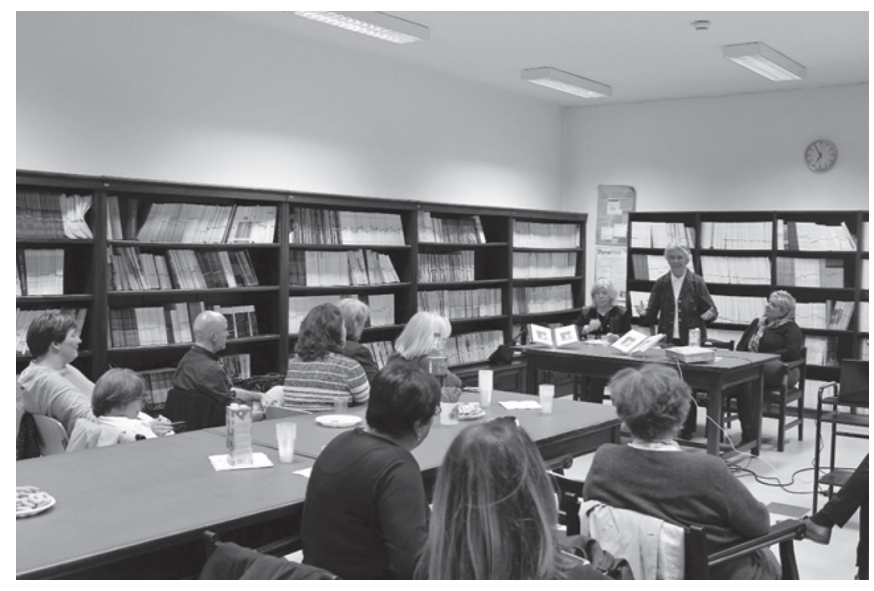

SLIKA [2] Predstavljanje knjige "I opet bih bila sestra - svjedok jednog vremena" Sanda Franković, Stana Lovrić, Rosana Svetić Čišić. 
skog okruženja. Čitajući knjigu, u tom bogatstvu uvida, svatko može naći ponešto za sebe: povijesnu građu, uvid u organizaciju bolničke službe, doprinos nacionalne udruge razvoju sestrinstva, stradanja i rad medicinskih sestara u Domovinskom ratu, materijale za nastavnički rad i još mnogo toga. Međutim, oni koji će knjigu čitati od korica do korica, njene fusnote i ono što piše između redova, u njoj će naći više od svjedočanstva jednog vremena. Autorica se u svojem izlaganju uzdiže iznad svakodnevice, iako u njoj djeluje, donoseći nam upravo ono što je za sestrinstvo bitno i ono što ima bezvremensko obilježje. Djelo u svojoj sveukupnosti daje poruku da sestrinstvo predstavlja stalno opredjeljenje i djelovanje u promicanju ideje humanosti i orijentiranosti prema čovjeku. Stoga knjiga autorice Stane Lovrić dolazi upravo u trenutku kada, stisnuti sveopćom racionalizacijom, izračunima, nadzorom kvalitete, cjeloživotnim obrazovanjem, međunarodnom razmjenom i zaglušeni bujicom pojmova koje nameće današnje društvo, ponekad ispustimo iz vida da je osnovni pojam našeg djelovanja - čovjek. Stoga knjiga "I opet bih bila sestra - svjedok jednog vremena" obogačuje čitatelja za uvid u sestrinstvo u toj njegovoj biti i, osim što je vrijedno preporučiti je svima koji sestrinstvo žive, treba je posebno preporučiti onima koji tek trebaju spoznati njegovu posebnost i ljepotu."

\section{Authors declare no conflict of interest}

\section{Literatura/References:}

[1] Noć knjige. Available at: http://nocknjige.hr/tekstx.php?id=18\&k=1, Accessed: May 2,2017.

[2] B. Jurinec, Noć knjige - Škola narodnog zdravlja "Andrija Štampar", Sestrinski glasnik, 2014; 19 (1), 69

[3] Petrak J. Noć knjige na Medicinskom fakultetu, List medicinskog fakulteta, srpanj 2013. 1:32:109

[4] Vinduška I, Jurinec B. Proslava - Noć knjige u 2014. godini - Škola narodnog zdravlja "Andrija Štampar", Sestrinski glasnik, 2014; 3 (19); 250

[5] Škorić L, Machala Poplašen L. Noć knjige na Medicinskom fakultetu, List medicinskog fakulteta, srpanj 2014; 1 (33): 109

[6] Franković S, Jurinec B. Obilježavanje Noći knjige 2015. godine - Škola narodnog zdravlja, Sestrinski glasnik, 2015; 20 (3); 281

[7] Vrkić D, Čuljak M, Machala Poplašen L. I treću godinu zaredom održana Noć knjige na Medicinskom fakultetu, List medicinskog fakulteta, 2015; 1 (34): 98-9

[8] Škorić L, Čuljak M. Noć knjige u knjižnicama medicinskog fakulteta, List medicinskog fakulteta, 2016; 1( 35): 97-8,

[9] Obilježavanje Noći knjige 22. travnja 2016. Available at: http://hums. hr/word/obiljezavanje-noci-knjige-22-travnja-2016-2/\#more-1048, Accessed: May $2^{\text {nd }} 2017$. 